\title{
Pemilihan Warga Penerima Bantuan Program Keluarga Harapan (PKH) Menggunakan Metode Simple Additive Weighting (SAW) dan User Acceptance Testing (UAT)
}

\author{
Pujianto $^{1}$, Mujito ${ }^{2}$, Danang Prabowo ${ }^{3}$, Basuki Hari Prasetyo ${ }^{4}$ \\ ${ }^{1,3}$ Teknik Informatika, Universitas Muhammadiyah Metro, Jl. KH Dewantara No.116 Iringmulyo, \\ Indonesia, 34381 \\ e-mail: ${ }^{1}$ pujianto@ummetro.ac.id, ${ }^{3}$ danangprabowo@ummetro.ac.id
${ }^{2}$ Sistem Informasi, Universitas Muhammadiyah Metro, Jl. KH Dewantara No.116 Iringmulyo, Indonesia, 34381
e-mail: ${ }^{2}$ mujito@ummetro.ac.id
${ }^{4}$ Teknik Informatika, Universitas Budi Luhur, Jl. Ciledug Raya, Indonesia, 12260 e-mail: ${ }^{4}$ basukihariprasetyo@bl.ac.id

Submitted Date: Agustus $31^{\text {th }}$, 2020

Revised Date: September $22^{\text {th }}, 2020$
Reviewed Date: September $22^{\text {th }}, 2020$

Accepted Date: September 30 ${ }^{\text {th }}, 2020$

\begin{abstract}
PKH (Hope Family Program) is a government assistance program to help people experiencing poverty problems this program is an aid from the ministry of social affairs in order to reduce social inequality among poor groups. so it is hoped that in the long run it can break the relationship of poverty between generations. so that the next generation can come out of the abyss of poverty due to the increasing quality of human resources produced. The aspects used are health aspects, educational aspects and aspects of social welfare. The selection of citizens who are not objective recipients of the PKH Program makes it a problem. Many protested against the village's devices in determining which residents were entitled to assistance and sometimes acts of vandalism. so that in this study want to help village devices in selecting citizens who are entitled to receive assistance using the system. The methods used are Simple Additive Weighting (SAW), and User Acceptance Testing (UAT) is used to test the feasibility of the application. A sample of 10 residents who were recommended to receive PKH assistance obtained the results that Mr. Anwar who ranked first for assistance with a score of 80.5 And for the testing UAT earned an average value of $87 \%$.
\end{abstract}

Keywords: PKH; program; village; Method; SAW; UAT.

\section{Abstrak}

Program Keluarga Harapan (PKH) adalah program bantuan pemerintah untuk membantu orangorang yang mengalami masalah kemiskinan program ini merupakan bantuan dari kementerian sosial dalam rangka mengurangi ketidaksetaraan sosial antara kelompok-kelompok miskin. sehingga generasi berikutnya dapat keluar dari jurang kemiskinan karena meningkatnya kualitas sumber daya manusia yang dihasilkan. Aspek-aspek yang digunakan adalah aspek kesehatan, aspek pendidikan dan aspek kesejahteraan sosial. Pemilihan warga bantuan penerima Program PKH yang tidak objektif membuatnya menjadi masalah. Banyak yang memprotes perangkat desa dalam menentukan penduduk mana yang berhak atas bantuan dan terkadang terjadi tindakan vandalisme. sehingga dalam penelitian ini ingin membantu perangkat desa dalam memilih warga yang berhak menerima bantuan menggunakan sistem. Metode yang digunakan adalah Simple Additive Weighting (SAW), dan User Acceptance Testing (UAT) digunakan untuk menguji kelayakan aplikasi. Sampel dari 10 warga yang direkomendasikan untuk menerima bantuan PKH diperoleh hasil bahwa Bapak Anwar yang menduduki peringkat pertama untuk bantuan dengan skor 80.5 dan untuk pengujian UAT diperoleh nilai rata-rata $87 \%$. 
Kata kunci : PKH; program; desa; Metode; SAW; UAT.

\section{Pendahuluan}

Program Keluarga Harapan atau yang sering disebut dengan PKH adalah program yang dicanangkan pemerintah melalui kementrian sosial (Astari, 2018). PKH adalah program pemberian bantuan sosial yang bersyarat diberikan kepada keluarga miskin yang ditetapkan sebagai keluarga penerima manfaat PKH. Pemerintah Indonesia sejak tahun 2007 telah melaksanakan program PKH sebagai upaya untuk menanggulangi kemiskinan warga Indonesia (Virgoreta, 2016).

Pemilihan warga yang dianggap miskin dan kurang mampu menjadi sebuah dilema bagi para perangkat desa didalam memetakan warga yang kurang mampu. Banyaknya warga yang kurang mampu pada suatu daerah menjadi permasalahan didalam memilih warga penerima bantuan Program Keluarga Harapan (PKH). Bantuan yang diberikan pemerintah melalui kementrian sosial dalam suatu desa tidak seimbang dengan jumlah warga yang masuk dalam kategori miskin atau tidak mampu sehingga perangkat desa harus benar-benar mampu memilih warga yang benarbenar tidak mampu. Aksi protes warga kerap terjadi ketika pemilihan tidak sesuai dengan kriteria warga yang dirasa kurang mampu, Pemilihan warga selama ini dilakukan dengan memilih secara langsung warga yang dirasa kurang mampu tanpa memperhatikan aspek-aspek yang lain, sehingga kerap terjadi kesalahan dalam memilih warga yang menerima bantuan. Melihat permasalahan dan pentingnya solusi untuk mengatasinya maka penelitian ini mengajukan sebuah metode yaitu Simple Additive Weighting (SAW) yang dapat melakukan proses perhitungan dan pemeringkatan secara otomatis (Wiyono, \& Latipah, 2017). Sehingga hasil dari penelitian ini adalah aplikasi sistem pendukung keputusan yang mampu memberikan rekomendasi kepada pihak perangkat desa mengenai siapa saja warga yang berhak menerima bantuan berdasarkan hasil perhitungan dari aspek-aspek yang dinilai.

Adapun Metode SAW dipilih karena sangat sesuai pada saat proses pengambilan sebuah keputusan hal ini dikarenakan metode SAW dapat memberikan sebuah nilai yang terbobot untuk setiap atributnya (Manullang, Prahutana, \& Santoso, 2018) dan sehingga dapat diproses hingga menghasilkan sebuah pemeringkatan dari proses seleksi alternatif terbaik dari beberapa alternatif terbaik (Poernomo, 2017). Selain itu, kelebihan model SAW ini jika dibandingkan dengan metode pengambilan keputusan lainnya adalah terletak pada kemampuannya untuk melakukan proses penilaian yang lebih tepat, hal ini dikarenakan nilai pada kriteria dan preferensi bobot nya sudah ditentukan (Refiza, 2019). Metode SAW ini juga sangat relevan didalam menyelesaikan sebuah permasalahan didalam pengambilan keputusan karena total perubahan sebuah nilai yang dihasilkan oleh metode SAW ini lebih banyak (Azfandi, \& Oktafianto, 2016).

Untuk pengujian kelayakan aplikasi menggunakan metode User Acceptance Testing (UAT). yaitu sebuah bentuk pengujian yang dilakukan oleh pihak akhir pengguna (end user). pihak akhir tersebut adalah pengguna yang akan langsung berinteraksi menggunakan sistem dan melakukan verifikasi terkait dengana fungsi apakah sudah berjalan dengan baik dan sesuai dengan fungsi beserta kebutuhannya (Firdaus, 2018).

Penelitian serupa yang membahas mengenai penerima bantuan menggunakan metode SAW telah dilakukan oleh Muhammad Alfaddin Salim. pada penelitian tersebut meneliti tentang kepala keluarga yang layak untuk mendapatkan bantuan berupa pembangunan renovasi atau perbaikan rumah serta pengadaan sarana yaitu sanitasi berdasarkan kriteria yang dimiliki oleh kepala keluarga tersebut. Kriteria yang digunakan sebanyak 13 kriteria dan menggunakan data kepala keluarga yang akan dipilih sebanyak 20 kepala keluarga. hasil penelitian yaitu peringkat dari calon penerima bantuan untuk renovasi atau perbaikan rumah dimulai dari yang layak mendapatkan hingga yang tidak layak mendapatkan bantuan (Salim, 2018). Kemudian penelitian yang menggunakan metode SAW juga dilakukan oleh Eva Yulianti dan Roki Z yang meneliti tentang pemilihan warga yang layak menerima bantuan bedah rumah. pada penelitian tersebut menggunakan beberapa mode yaitu Kondisi model kondisi rumah, model penghasilan dan model Aset Pribadi. hasil penelitian adalah aplikasi yang mampu menghasilkan bentuk keluaran berupa pemeringkatan mulai dari yang tertinggi nilainya sampai dengan terendah (Yulianti, \& Roki, 2018). Penelitian selanjutnya yang membahas mengenai penerima bantuan menggunakan metode SAW dilakukan oleh $\mathrm{M}$. Ari Effendi dan Oktafianto. pada penelitiannya 
membahas mengenai siapa saja siswa miskin yang layak mendapatkan bantuan. adapun kriteria yang digunakan pada penelitian tersebut yaitu gaji orang tua, jumlah tanggungan, prestasi akademik, nilai rapor dan kelas. penilaian menggunakan skala fuzzy yaitu Sangat rendah, rendah, sedang, tengah, tinggi dan sangat tinggi. hasil penelitiannya adalah sebuah aplikasi yang dibangun menggunakan VB.6 dan bentuk keluarannya berupa rekomendasi siswa yang layak mendapatkan bantuan (Effendi, \& Oktafianto, 2017).

\section{Metode}

Adapun metode penelitian digunakan dengan maksud dan tujuan untuk menggambarkan secara terperinci proses dari penelitian yang berjalan, proses diawali dari collecting data hingga pada tahap pengujian sistem (Anwar, \& Kurniawan, 2019). Berikut adalah metode penelitian secara keseluruhan:

a. Collecting Data

Proses awal dari penelitian ini diawali dengan cara mengumpulkan data-data dari sumber yang terkait dengan pemilihan warga penerima bantuan, yaitu data warga dan data kriteria yang akan digunakan.

b. Mengolah Data

Tahapan berikutnya setelah selesai mengumpulkan data penelitian adalah pengolahan data penelitian, data-data tersebut akan diolah menggunakan algoritma SAW.

c. Mengembangkan Sistem

Pada tahap mengembakankan sistem ini akan dibahas mengenai bentuk rancangan sistem atau interface yang akan digunakan. Sehingga proses proses pemilihan warga penerima bantuan dalam bentuk aplikasi dapat digambarkan dengan jelas.

d. Implementasi Sistem

Langkah berikutnya setelah pengembangan sistem yakni mengimplementasikan aplikasi sistem pendukung keputusan. Algoritma dari Simple Additive Weighting (SAW) diimplementasikan kedalam sistem. Sehingga Aplikasi dapat berjalan dengan baik dan sesuai dengan kebutuhan dari user.

e. Pengujian Sistem

Langkah yang terakhir yakni menguji sistem atau aplikasi sistem pendukung keputusan yang telah berhasil dibuat. Pada tahap ini pengujian sistem akan ditest menggunakan model User Acceptance Test (UAT) sehingga aplikasi yang berhasil dibangun benar-benar sesuai dengan kebutuhan dari user. Sehingga hasil akhir penelitian adalah sebuah aplikasi Sistem Pendukung Keputusan dengan bentuk hasil keluaran yang akurat jika dihitung menggunakan SAW. Serta dapat membantu pihak pengambil keputusan didalam memilih warga penerima bantuan.

\section{Hasil dan Pembahasan}

Berikut adalah contoh perhitungan pemilihan warga penerima bantuan Program Keluarga Harapan (PKH) yang menggunakan sample data warga sebanyak 10 Warga. Adapun data-data warga ditunjukkan pada Tabel 1, data kriteria ditunjukkan pada Tabel 2, sedangkan pembobotan ditunjukkan pada Tabel 3 sampai dengan Tabel 11.

Table 1. Data Warga

\begin{tabular}{|l|l|l|}
\hline Kode & \multicolumn{1}{|c|}{ Nama } & \multicolumn{1}{c|}{ Alamat } \\
\hline W1 & Muhammad Toha & Jl. Manggis Ds 1 \\
\hline W2 & Abdul Aziz & Jl. Nanas Ds 2 \\
\hline W3 & Tutik & Jl. Manggis Ds 1 \\
\hline W4 & Amin Nuroni & Jl. Nanas Dusun 2 \\
\hline W5 & Watik & Jl. Manggis Ds 1 \\
\hline W6 & Kurniawan & Jl. Durian Ds 3 \\
\hline W7 & Lela Nurjanah & Jl. Durian Ds 3 \\
\hline W8 & Ika Nurjanah & Jl. Manggis Ds 1 \\
\hline W9 & Anwar & Jl. Nanas Dusun 2 \\
\hline W10. & Elmayanti & Jl. Manggis Ds 1 \\
\hline
\end{tabular}

Table 2. Data Kriteria

\begin{tabular}{|l|l|l|l|}
\hline Kode & Nama Kriteria & Attribut & Bobot \\
\hline C1 & Ibu Hamil & Benefit & 20 \\
\hline C2 & Ibu Menyusui & Cost & 10 \\
\hline C3 & $\begin{array}{l}\text { Anak Berusia 0 -5 } \\
\text { tahun }\end{array}$ & Cost & 10 \\
\hline C4 & Anak SD & Benefit & 5 \\
\hline C5 & Anak SMP & Benefit & 5 \\
\hline C6 & Anak SMA & Benefit & 5 \\
\hline C7 & $\begin{array}{l}\text { Anak Usia 6 - 21 } \\
\text { tahun belum wajib } \\
\text { belajar 12 tahun }\end{array}$ & Cost & 5 \\
\hline C8 & Lanjut Usia & Benefit & 15 \\
\hline C9 & $\begin{array}{l}\text { Penyandang } \\
\text { Disabilitas }\end{array}$ & Benefit & 25 \\
\hline
\end{tabular}

Table 3. Pembobotan

\begin{tabular}{|l|l|}
\hline \multicolumn{1}{|c|}{ Pembobotan } & Nilai \\
\hline Sangat Tinggi & 5 \\
\hline Tinggi & 4 \\
\hline Cukup & 3 \\
\hline Rendah & 2 \\
\hline Sangat Rendah & 1 \\
\hline
\end{tabular}


Table 4. Pembobotan Ibu Hamil

\begin{tabular}{|l|l|}
\hline \multicolumn{1}{|c|}{ Pembobotan } & Nilai \\
\hline Usia Kandungan $8-9$ bulan & 5 \\
\hline Usia Kandungan $6-7$ bulan & 4 \\
\hline Usia Kandungan $4-5$ bulan & 3 \\
\hline Usia Kandungan $2-3$ bulan & 2 \\
\hline Usia Kandungan $0-1$ bulan & 1 \\
\hline
\end{tabular}

Table 5. Pembobotan Ibu Menyusui

\begin{tabular}{|l|l|}
\hline Pembobotan & Nilai \\
\hline Usia Bayi $10-12$ bulan & 5 \\
\hline Usia Bayi $13-14$ bulan & 4 \\
\hline Usia Bayi $15-17$ bulan & 3 \\
\hline Usia Bayi $18-20$ bulan & 2 \\
\hline Usia Bayi $>20$ bulan & 1 \\
\hline
\end{tabular}

Table 6. Pembobotan Anak usia 0 -5 tahun

\begin{tabular}{|l|l|}
\hline \multicolumn{1}{|c|}{ Pembobotan } & Nilai \\
\hline Usia Anak 0- 1 Tahun & 5 \\
\hline Usia Anak 2 Tahun & 4 \\
\hline Usia Anak 3 Tahun & 3 \\
\hline Usia Anak 4 Tahun & 2 \\
\hline Usia Anak 5 Tahun & 1 \\
\hline
\end{tabular}

Table 7. Pembobotan Anak SD

\begin{tabular}{|l|l|}
\hline \multicolumn{1}{|c|}{ Pembobotan } & Nilai \\
\hline Jumlah Anak SD 5 Anak & 5 \\
\hline Jumlah Anak SD 4 Anak & 4 \\
\hline Jumlah Anak SD 3 Anak & 3 \\
\hline Jumlah Anak SD 2 Anak & 2 \\
\hline Jumlah Anak SD 1 Anak & 1 \\
\hline
\end{tabular}

Table 7. Pembobotan Anak SMP

\begin{tabular}{|l|l|}
\hline \multicolumn{1}{|c|}{ Pembobotan } & Nilai \\
\hline Jumlah Anak SMP 5 Anak & 5 \\
\hline Jumlah Anak SMP 4 Anak & 4 \\
\hline Jumlah Anak SMP 3 Anak & 3 \\
\hline Jumlah Anak SMP 2 Anak & 2 \\
\hline Jumlah Anak SMP 1 Anak & 1 \\
\hline
\end{tabular}

Table 8. Pembobotan Anak SMA

\begin{tabular}{|l|l|}
\hline \multicolumn{1}{|c|}{ Pembobotan } & Nilai \\
\hline Jumlah Anak SMA 5 Anak & 5 \\
\hline Jumlah Anak SMA 4 Anak & 4 \\
\hline Jumlah Anak SMA 3 Anak & 3 \\
\hline Jumlah Anak SMA 2 Anak & 2 \\
\hline Jumlah Anak SMA 1 Anak & 1 \\
\hline
\end{tabular}

Table 9. Pembobotan Anak Usia 6 - 21 tahun belum wajib belajar 12 tahun

\begin{tabular}{|l|l|}
\hline \multicolumn{1}{|c|}{ Pembobotan } & Nilai \\
\hline Usia Anak 6-8 Tahun & 5 \\
\hline Usia Anak 9-11 Tahun & 4 \\
\hline Usia Anak 12-14 Tahun & 3 \\
\hline Usia Anak 15-18 Tahun & 2 \\
\hline Usia Anak 19 - 21 Tahun & 1 \\
\hline
\end{tabular}

Table 10. Pembobotan Lanjut Usia

\begin{tabular}{|l|l|}
\hline \multicolumn{1}{|c|}{ Pembobotan } & Nilai \\
\hline Usia > 76 Tahun & 5 \\
\hline Usia 71 - 75 Tahun & 4 \\
\hline Usia 66 - 70 Tahun & 3 \\
\hline Usia 61 - 65 Tahun & 2 \\
\hline Usia 50-60 Tahun & 1 \\
\hline
\end{tabular}

Table 11. Pembobotan Penyandang Disabilitas

\begin{tabular}{|l|l|}
\hline \multicolumn{1}{|c|}{ Pembobotan } & Nilai \\
\hline Sangat Parah & 5 \\
\hline Parah & 4 \\
\hline Sedang & 3 \\
\hline Rendah & 2 \\
\hline Sangat Rendah & 1 \\
\hline
\end{tabular}

A. Proses Simple Additive Weighting (SAW) Pada tahap pertama dari proses SAW adalah memberikan penilaian pada masing-masing calon penerima bantuan Program Keluarga Harapan (PKH).

Table 12. Penilaian Warga

\begin{tabular}{|l|l|l|l|l|l|l|l|l|l|}
\hline & C1 & C2 & C3 & C4 & C5 & C6 & C7 & C8 & C9 \\
\hline W1 & 5 & 3 & 5 & 2 & 1 & 2 & 1 & 1 & 3 \\
\hline W2 & 4 & 2 & 1 & 3 & 2 & 3 & 2 & 5 & 2 \\
\hline W3 & 4 & 4 & 1 & 4 & 3 & 4 & 3 & 3 & 4 \\
\hline W4 & 3 & 5 & 2 & 2 & 3 & 1 & 4 & 2 & 3 \\
\hline W5 & 4 & 5 & 3 & 1 & 4 & 1 & 3 & 1 & 4 \\
\hline W6 & 5 & 4 & 1 & 1 & 5 & 3 & 3 & 1 & 1 \\
\hline W7 & 2 & 3 & 2 & 3 & 2 & 2 & 2 & 3 & 1 \\
\hline W8 & 1 & 2 & 2 & 4 & 2 & 4 & 1 & 4 & 1 \\
\hline W9 & 4 & 1 & 1 & 2 & 1 & 5 & 1 & 2 & 4 \\
\hline W10 & 5 & 2 & 3 & 1 & 1 & 1 & 1 & 5 & 3 \\
\hline
\end{tabular}

Langkah berikutnya adalah melakukan proses normalisasi. Pada proses normalisasi perlu diperhatikan tipe attribut dari setiap kriteria. untuk attribut yang bertipe Benefit maka semakin tinggi nilai maka akan semakin baik. Namun jika bertipe Cost maka semakin kecil nilai maka akan semakin baik. Berikut proses perhitungan normalisasi.

Pada kriteria Ibu Hamil (C1) berattribut Benefit maka kita cari nilai Max dari (5, 4, 4, 3, 4, 5, 2, $1,4,5)$ yaitu 5. Sehingga

$\mathrm{W} 1=5 / 5=1, \mathrm{~W} 2=4 / 5=0.8, \mathrm{~W} 3=4 / 5=0.8$, $\mathrm{W} 4=3 / 5=0.6, \mathrm{~W} 5=4 / 5=0.8, \mathrm{~W} 6=5 / 5=1$, $\mathrm{W} 7=2 / 5=0.4, \mathrm{~W} 8=1 / 5=0.2, \mathrm{~W} 9=4 / 5=$ $0.8, \mathrm{~W} 10=5 / 5=1$.

Pada kriteria Ibu Menyusui (C2) berattribut Cost maka kita cari nilai Min dari $(3,2,4,5,5,4,3$, $2,1,2)$ yaitu 1 . Sehingga 
$\mathrm{W} 1=1 / 3=0.33, \mathrm{~W} 2=1 / 2=0.5, \mathrm{~W} 3=1 / 4=$ $0.25, \mathrm{~W} 4=1 / 5=0.2, \mathrm{~W} 5=1 / 5=0.2, \mathrm{~W} 6=1$ $14=0.25, \mathrm{~W} 7=1 / 3=0.33, \mathrm{~W} 8=1 / 2=0.5$, $\mathrm{W} 9=1 / 1=0.8, \mathrm{~W} 10=1 / 2=0.5$

Pada kriteria Anak usia 0 -5 tahun (C3) berattribut Cost maka kita cari nilai Min dari (5, $1,1,2,3,1,2,2,1,3)$ yaitu 1 . Sehingga

$\mathrm{W} 1=1 / 5=0.2, \mathrm{~W} 2=1 / 1=1, \mathrm{~W} 3=1 / 1=1$, $\mathrm{W} 4=1 / 2=0.5, \mathrm{~W} 5=1 / 3=0.33, \mathrm{~W} 6=1 / 1=$ $1, \mathrm{~W} 7=1 / 2=0.5, \mathrm{~W} 8=1 / 2=0.5, \mathrm{~W} 9=1 / 1=$ $1, \mathrm{~W} 10=1 / 3=0.33$.

Pada kriteria Anak SD (C4) berattribut Benefit maka kita cari nilai Max dari $(2,3,4,2,1,1,3$, $4,2,1)$ yaitu 4. Sehingga

$\mathrm{W} 1=2 / 4=0.5, \mathrm{~W} 2=3 / 4=0.75, \mathrm{~W} 3=4 / 4=$ $1, \mathrm{~W} 4=2 / 4=0.5, \mathrm{~W} 5=1 / 4=0.25, \mathrm{~W} 6=1 / 4$ $=0.25, \mathrm{~W} 7=3 / 4=0.75, \mathrm{~W} 8=4 / 4=1, \mathrm{~W} 9=2$ $/ 4=0.25, \mathrm{~W} 10=1 / 4=0.25$.

Pada kriteria Anak SMP (C5) berattribut Benefit maka kita cari nilai Max dari $(1,2,3,3,4,5,2$, $2,1,1)$ yaitu 5 . Sehingga

$\mathrm{W} 1=1 / 5=0.2, \mathrm{~W} 2=2 / 5=0.4, \mathrm{~W} 3=3 / 5=$ $0.6, \mathrm{~W} 4=3 / 5=0.6, \mathrm{~W} 5=4 / 5=0.8, \mathrm{~W} 6=5 / 5$ $=1, \mathrm{~W} 7=2 / 5=0.4, \mathrm{~W} 8=2 / 5=0.4, \mathrm{~W} 9=1 / 5$ $=0.2, \mathrm{~W} 10=1 / 5=0.2$.

Pada kriteria Anak SMA (C6) berattribut Benefit maka kita cari nilai Max dari $(2,3,4,1$, $1,3,2,4,5,1)$ yaitu 5 . Sehingga

$\mathrm{W} 1=2 / 5=0.4, \mathrm{~W} 2=3 / 5=0.6, \mathrm{~W} 3=4 / 5=$ $0.8, \mathrm{~W} 4=1 / 5=0.2, \mathrm{~W} 5=1 / 5=0.2, \mathrm{~W} 6=3 / 5$ $=0.6, \mathrm{~W} 7=2 / 5=0.4, \mathrm{~W} 8=4 / 5=0.8, \mathrm{~W} 9=5$ $15=1, \mathrm{~W} 10=1 / 5=0.2$.

Pada kriteria Anak Usia 6 - 21 tahun belum wajib belajar 12 tahun (C7) berattribut Cost maka kita cari nilai Min dari $(1,2,3,4,3,3,2$, $1,1,1)$ yaitu 1 . Sehingga

$\mathrm{W} 1=1 / 1=1, \mathrm{~W} 2=1 / 2=0.5, \mathrm{~W} 3=1 / 3=$ $0.33, \mathrm{~W} 4=1 / 4=0.25$, W5 $=1 / 3=0.33$, W6 = $1 / 3=0.33, \mathrm{~W} 7=1 / 2=0.5, \mathrm{~W} 8=1 / 1=1, \mathrm{~W} 9$ $=1 / 1=1, \mathrm{~W} 10=1 / 1=1$.

Pada kriteria Lanjut Usia (C8) berattribut Benefit maka kita cari nilai Max dari $(1,5,3,2$, $1,1,3,4,2,5)$ yaitu 5 . Sehingga

$\mathrm{W} 1=1 / 5=0.2, \mathrm{~W} 2=5 / 5=1, \mathrm{~W} 3=3 / 5=0.6$, $\mathrm{W} 4=2 / 5=0.8, \mathrm{~W} 5=1 / 5=0.2, \mathrm{~W} 6=1 / 5=$ $0.2, \mathrm{~W} 7=3 / 5=0.6, \mathrm{~W} 8=4 / 5=0.8, \mathrm{~W} 9=2 / 5$ $=0.4, \mathrm{~W} 10=5 / 5=1$.

Pada kriteria Penyandang Disabilitas (C9) berattribut Benefit maka kita cari nilai Max dari $(3,2,4,3,4,1,1,1,4,3)$ yaitu 4. Sehingga

$\mathrm{W} 1=3 / 4=0.75, \mathrm{~W} 2=2 / 4=0.5, \mathrm{~W} 3=4 / 4=$ $1, \mathrm{~W} 4=3 / 4=0.75, \mathrm{~W} 5=4 / 4=1, \mathrm{~W} 6=1 / 4=$
$0.25, \mathrm{~W} 7=1 / 4=0.25, \mathrm{~W} 8=1 / 4=0.25, \mathrm{~W} 9=$ $4 / 4=1, W 10=3 / 4=0.75$.

Sehingga jika dimasukan kedalam tabel penilaian warga adalah sebagai berikut :

Table 13. Normalisasi Nilai Warga

\begin{tabular}{|l|l|l|l|l|l|l|}
\hline & C1 & C2 & C3 & C4 & C5 & C6 \\
\hline W1 & 1 & 0.33 & 0.2 & 0.5 & 0.2 & 0.4 \\
\hline W2 & 0.8 & 0.5 & 1 & 0.75 & 0.4 & 0.6 \\
\hline W3 & 0.8 & 0.25 & 1 & 1 & 0.6 & 0.8 \\
\hline W4 & 0.6 & 0.2 & 0.5 & 0.5 & 0.6 & 0.2 \\
\hline W5 & 0.8 & 0.2 & 0.33 & 0.25 & 0.8 & 0.2 \\
\hline W6 & 1 & 0.25 & 1 & 0.25 & 1 & 0.6 \\
\hline W7 & 0.4 & 0.33 & 0.5 & 0.75 & 0.4 & 0.4 \\
\hline W8 & 0.2 & 0.5 & 0.5 & 1 & 0.4 & 0.8 \\
\hline W9 & 0.8 & 1 & 1 & 0.5 & 0.2 & 1 \\
\hline W10 & 1 & 0.5 & 0.33 & 0.25 & 0.2 & 0.2 \\
\hline
\end{tabular}

\begin{tabular}{|l|l|l|}
\hline C7 & C8 & C9 \\
\hline 1 & 0.2 & 0.75 \\
\hline 0.5 & 1 & 0.5 \\
\hline 0.33 & 0.6 & 1 \\
\hline 0.25 & 0.8 & 0.75 \\
\hline 0.33 & 0.2 & 1 \\
\hline 0.33 & 0.2 & 0.25 \\
\hline 0.5 & 0.6 & 0.25 \\
\hline 1 & 0.8 & 0.25 \\
\hline 1 & 0.4 & 1 \\
\hline 1 & 1 & 0.75 \\
\hline
\end{tabular}

Langkah selanjutnya adalah proses pemeringkatan, yaitu mengalikan bobot nilai normalisasi dikalikan dengan bobot kriteria. proses pemeringkatan adalah sebagai berikut:

$\mathrm{W} 1:(1 * 20)+(0.33 * 10)+(0.2 * 10)+(0.5 * 5)+$ $(0.2 * 5)+(0.4 * 5)+(1 * 5)+(0.2 * 15)+(0.7 * 25)$ $=57.58$.

$\mathrm{W} 2:(0.8 * 20)+(0.5 * 10)+(1 * 10)+(0.75 * 5)+$ $(0.4 * 5)+(0.6 * 5)+(0.5 * 5)+(1 * 15)+(0.5 * 25)$ $=69.75$.

$\mathrm{W} 3:(0.8 * 20)+(0.25 * 10)+(1 * 10)+(1 * 5)+$ $(0.6 * 5)+(0.8 * 5)+(0.33 * 5)+(0.6 * 15)+(1 *$ $25)=76.17$.

$\mathrm{W} 4:(0.6 * 20)+(0.2 * 10)+(0.5 * 10)+(0.5 * 5)+$ $(0.6 * 5)+(0.2 * 5)+(0.25 * 5)+(0.8 * 15)+(0.75 *$ 25) $=57.5$.

$\mathrm{W} 5:(0.8 * 20)+(0.2 * 10)+(0.33 * 10)+$ $(0.25 * 5)+(0.8 * 5)+(0.2 * 5)+(0.33 * 5)+$ $(0.2 * 15)+(1 * 25)=57.25$. 
W6 : $(1 * 20)+(0.25 * 10)+(1 * 10)+(0.25 * 5)+$ $(1 * 5)+(0.6 * 5)+(0.33 * 5)+(0.2 * 15)+(0.25 *$ $25)=52.67$.

$\mathrm{W} 7:(0.4 * 20)+(0.33 * 10)+(0.5 * 10)+$ $(0.75 * 5)+(0.4 * 5)+(0.4 * 5)+(0.5 * 5)+$ $(0.6 * 15)+(0.25 * 25)=41.83$.

$\mathrm{W} 8:(0.2 * 20)+(0.5 * 10)+(0.5 * 10)+(1 * 5)+$ $(0.4 * 5)+(0.8 * 5)+(1 * 5)+(0.8 * 15)+(0.25 *$ $25)=48.25$.

W9 : $(0.8 * 20)+(1 * 10)+(1 * 10)+(0.5 * 5)+$ $(0.2 * 5)+(1 * 5)+(1 * 5)+(0.4 * 15)+(1 * 25)=$ 80.5 .

$\mathrm{W} 10:(1 * 20)+(0.5 * 10)+(0.33 * 10)+(0.25 * 5)$ $+(0.2 * 5)+(0.2 * 5)+(1 * 5)+(1 * 15)+(0.75 *$ 25) $=70.33$.

B. Bentuk Tampilan Aplikasi

Berikut adalah bentuk sebagian dari tampilan aplikasi.

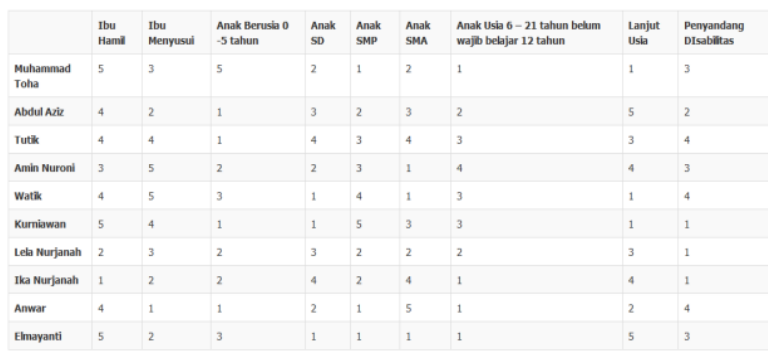

Gambar 1. Penilaian Warga

\begin{tabular}{|c|c|c|c|c|c|c|c|c|c|}
\hline \multicolumn{10}{|c|}{ Mormakas } \\
\hline & c001 & $c 002$ & $c 003$ & c004 & coos & 0006 & $c 007$ & C008 & $c 009$ \\
\hline A001 & 1 & 0.33 & 0.2 & 0.5 & 0.2 & 0.4 & 1 & 0.2 & 0.75 \\
\hline A002 & 0.8 & 0.5 & 1 & 0.75 & 0.4 & 0.6 & 0.5 & 1 & 0.5 \\
\hline A003 & 0.8 & 0.25 & 1 & 1 & 0.6 & 0.8 & 0.33 & 0.6 & 1 \\
\hline A004 & 0.6 & 0.2 & 0.5 & 0.5 & 0.6 & 0.2 & 0.25 & 0.8 & 0.75 \\
\hline A005 & 0.8 & 0.2 & 0.33 & 0.25 & 0.8 & 0.2 & 0.33 & 0.2 & 1 \\
\hline A006 & 1 & 0.25 & 1 & 0.25 & 1 & 0.6 & 0.33 & 0.2 & 0.25 \\
\hline A007 & 0.4 & 0.33 & 0.5 & 0.75 & 0.4 & 0.4 & 0.5 & 0.6 & 0.25 \\
\hline A00B & 0.2 & 0.5 & 0.5 & 1 & 0.4 & 0.8 & 1 & 0.8 & 0.25 \\
\hline A009 & 0.8 & 1 & 1 & 0.5 & 0.2 & 1 & 1 & 0.4 & 1 \\
\hline A010 & 1 & 0.5 & 0.33 & 0.25 & 0.2 & 0.2 & 1 & 1 & 0.75 \\
\hline
\end{tabular}

Gambar 2. Bobot Normalisasi

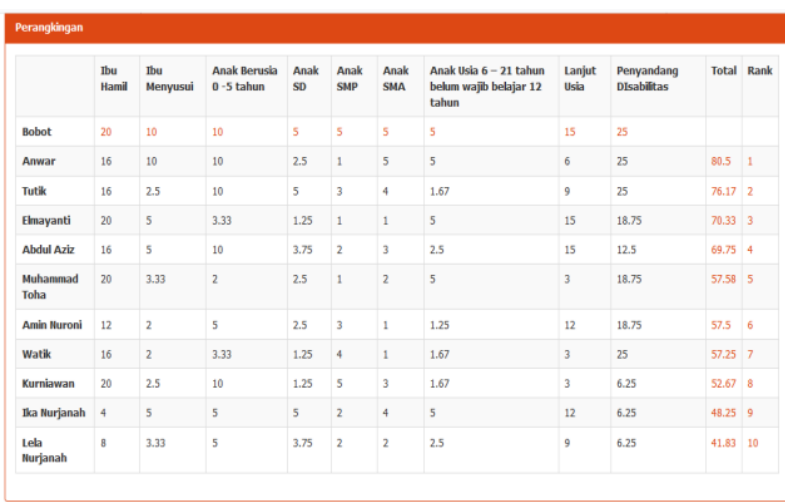

Gambar 3. Proses Pemeringkatan

C. User Acceptance Testing (UAT)

Pengujian dengan metode UAT ini dilakukan dengan cara mengajukan sejumlah pertanyaan terhadap para pihak pengambil keputusan. pengujian ini menggunakan 10 orang perangkat desa yang akan memilih para warga penerima bantuan PKH. pilihan jawaban dari UAT menggunakan 5 buah kategori, Sangat Sesuai (SS), Sesuai (S), Kurang Sesuai (KS), TIdak Sesuai (TS) kemudian Tidak Jawab (TJ).

Sedangkan untuk penilaian bobot nilai pada hasil jawaban adalah sebagai berikut:

Table 14. penilaian bobot nilai jawaban

\begin{tabular}{|l|l|}
\hline Jawaban & Bobot \\
\hline (SS) Sangat Sesuai & 5 \\
\hline (S) Sesuai & 4 \\
\hline (KS) Kurang Sesuai & 3 \\
\hline (TS) Tidak Sesuai & 2 \\
\hline (TJ) Tidak Jawab & 1 \\
\hline
\end{tabular}

Table 15. Pertanyaan Kuesioner

\begin{tabular}{|c|c|c|c|c|c|c|}
\hline No & Pertanyaan & A & B & $\mathbf{C}$ & $\mathbf{D}$ & $\mathbf{E}$ \\
\hline 1 & $\begin{array}{l}\text { Aplikasi berjalan sesuai kebutuhan dari bapak/ibu dalam memilih warga } \\
\text { penerima bantuan }\end{array}$ & & & & & \\
\hline 2 & Aplikasi mempermudah didalam pemilihan warga penerima bantuan & & & & & \\
\hline 3 & informasi dari aplikasi sangat akurat & & & & & \\
\hline 4 & Aplikasi ini menyediakan tingkat pengamanan data yang baik & & & & & \\
\hline 5 & aplikasi dapat berjalan walaupun terjadi kesalahan didalam entry data & & & & & \\
\hline 6 & Adanya pesan kesalahan untuk user ketika ada kesalahan didalam entry data & & & & & \\
\hline 7 & Aplikasi ini mudah untuk digunakan & & & & & \\
\hline 8 & Aplikasi tidak menyulitkan dalam pengentryan data warga & & & & & \\
\hline 9 & Bapak/Ibu merasa nyaman dengan tampilan aplikasi ini & & & & & \\
\hline
\end{tabular}


Kemudian setelah perangkat desa memberikan jawaban terkait dengan pertanyaan kuesioner tersebut maka didapatkan hasil sebagai berikut

Table 16. Jawaban Kuesioner

\begin{tabular}{|l|l|l|l|l|l|l|}
\hline No & \multicolumn{1}{|c|}{ Pertanyaan } & A & B & C & D & E \\
\hline 1 & $\begin{array}{l}\text { Secara umum aplikasi ini sesuai dengan kebutuhan bapak / ibu dalam } \\
\text { memilih warga penerima bantuan }\end{array}$ & 6 & 1 & & \\
\hline 2 & $\begin{array}{l}\text { Adanya Aplikasi ini mempermudah bapak / ibu dalam memilih warga } \\
\text { penerima bantuan }\end{array}$ & 8 & 1 & & \\
\hline 3 & Informasi yang dihasilkan oleh aplikasi ini akurat & 7 & 3 & & & \\
\hline 4 & Aplikasi ini menyediakan tingkat pengamanan data yang baik & 5 & 3 & 1 & 1 & \\
\hline 5 & $\begin{array}{l}\text { Aplikasi ini tetap dapat berjalan dengan baik meski ada kekeliruan dalam } \\
\text { memasukkan data }\end{array}$ & 2 & 2 & 1 & \\
\hline 6 & Aplikasi ini menyediakan pesan kesalahan untuk pengguna & 7 & 2 & 1 & & \\
\hline 7 & Aplikasi ini mudah untuk digunakan & 6 & 2 & 2 & & \\
\hline 8 & Aplikasi tidak menyulitkan dalam pengentryan data warga & 5 & 3 & 1 & 1 & \\
\hline 9 & Bapak/Ibu merasa nyaman dengan tampilan aplikasi ini & 6 & 1 & 1 & 2 & \\
\hline
\end{tabular}

Setelah kuesioner pertanyaan diisi oleh para perangkat desa yang akan memilih warga penerima bantuan Program Keluarga Harapan maka proses berikutnya adalah mengalikan nilai jawaban dengan nilai bobot yang telah ditentukan. sehingga diperoleh hasil sebagai berikut

Table 17. Pengolahan data kuesioner

\begin{tabular}{|l|l|l|l|l|l|l|l|}
\hline No & \multicolumn{1}{|c|}{ Pertanyaan } & A & B & C & D & E & total \\
\hline 1 & $\begin{array}{l}\text { Secara umum aplikasi ini sesuai dengan kebutuhan bapak / ibu dalam } \\
\text { memilih warga penerima bantuan }\end{array}$ & 30 & 12 & 3 & & & 45 \\
\hline 2 & $\begin{array}{l}\text { Adanya Aplikasi ini mempermudah bapak / ibu dalam memilih warga } \\
\text { penerima bantuan }\end{array}$ & 40 & 4 & 3 & & 47 \\
\hline 3 & Informasi yang dihasilkan oleh aplikasi ini akurat & 35 & 12 & & & & 47 \\
\hline 4 & Aplikasi ini menyediakan tingkat pengamanan data yang baik & 25 & 12 & 3 & 2 & & 42 \\
\hline 5 & $\begin{array}{l}\text { Aplikasi ini tetap dapat berjalan dengan baik meski ada kekeliruan dalam } \\
\text { memasukkan data }\end{array}$ & 25 & 8 & 6 & 2 & & 41 \\
\hline 6 & Aplikasi ini menyediakan pesan kesalahan untuk pengguna & 35 & 8 & 3 & & & 46 \\
\hline 7 & Aplikasi ini mudah untuk digunakan & 30 & 8 & 6 & & 44 \\
\hline 8 & Aplikasi tidak menyulitkan dalam pengentryan data warga & 25 & 12 & 3 & 2 & & 41 \\
\hline 9 & Bapak/Ibu merasa nyaman dengan tampilan aplikasi ini & 30 & 4 & 3 & 4 & 41 \\
\hline
\end{tabular}

Berdasarkan pertanyaan pertama diperoleh total nilai 45. Sehingga nilai rata-rata adalah $45 / 10=4.5$. dan prosentase nilaianya adalah $4.5 / 5 \times 100=90 \%$.

pertanyaan kedua diperoleh total nilai 47 . Sehingga nilai rata-rata adalah $47 / 10=4.7$. dan prosentase nilaianya adalah $4.7 / 5 \times 100$ $=94 \%$.

pertanyaan ketiga diperoleh total nilai 47 . Sehingga nilai rata-rata adalah $47 / 10=4.7$. dan prosentase nilaianya adalah $4.7 / 5 \times 100$ $=94 \%$.

pertanyaan keempat diperoleh total nilai 42 . Sehingga nilai rata-rata adalah $42 / 10=4.2$. dan prosentase nilaianya adalah $4.2 / 5 \times 100$ $=84 \%$. pertanyaan kelima diperoleh total nilai 41 . Sehingga nilai rata-rata adalah 41/10 $=4.1$. dan prosentase nilaianya adalah $4.1 / 5 \times 100$ $=82 \%$.

pertanyaan keenam diperoleh total nilai 46 . Sehingga nilai rata-rata adalah $46 / 10=4.6$. dan prosentase nilaianya adalah $4.6 / 5 \times 100$ $=92 \%$.

pertanyaan ketujuh diperoleh total nilai 44 . Sehingga nilai rata-rata adalah $44 / 10=4.4$. dan prosentase nilaianya adalah $4.4 / 5 \times 100$ $=88 \%$.

pertanyaan kedelapan diperoleh total nilai 41. Sehingga nilai rata-rata adalah $41 / 10=$ 4.1. dan prosentase nilaianya adalah $4.1 / 5$ $\mathrm{x} 100=82 \%$. 
pertanyaan kesembilan diperoleh total nilai 41. Sehingga nilai rata-rata adalah $41 / 10=$ 4.1. dan prosentase nilaianya adalah $4.1 / 5 \mathrm{x}$ $100=82 \%$.

\section{Kesimpulan}

Berdasarkan hasil dan pembahasan mengenai perhitungan menggunakan metode SAW dan pengujian aplikasi menggunakan metode User Acceptance Testing (UAT) maka dapat disimpulkan yaitu untuk daftar warga yang direkomendasikan menerima bantuan adalah bapak Anwar dengan perolehan nilai sebesar 80.5 dan untuk pengujian aplikasi diperoleh rata-rata nilai sebesar $87 \%$ sehingga dapat dikatakan user atau pengguna aplikasi merasa puas dan terbantu dengan adanya aplikasi ini.

\section{Referensi}

Anwar, M. A. H., \& Kurniawan, Y. (2019). Dokumentasi Software Testing Berstandar Ieee 829-2008 Untuk Sistem Informasi Terintegrasi. KURAWAL Jurnal Teknologi, Informasi Dan Industri, 2, 118-125.

Astari, N. P. (2018). Implementasi Program Keluarga Harapan (PKH) Oleh Pelaksana Program Keluarga Harapan (PPKH) Dalam Meningkatkan Partisipasi Pendidikan (Studi di Kecamatan Rajadesa Kabupaten Ciamis). DINAMIKA, 5, 133-140.

Azfandi, A., \& Oktafianto. (2016). Sistem Pendukung Keputusan Pemilihan Laptop Dengan Metode Simple Additive Weighting (SAW) Studi Kasus : Raka Com. Konferensi Mahasiswa Sistem Informasi STMIK PRNGSEWU, 4(1), 39-43. Retrieved from http://ojs.stmikpringsewu.ac.id/index.php/procidi ngkmsi/article/view/392/369

Effendi, A, M. \& Oktafianto. (2017). Bantuan Siswa Miskin Dengan Metode Simple Additive Weighting ( Studi Kasus SMK Roudlotul Huda Purwosari ) Jl . Wisma Rini No . 19 Pringsewu Lampung, 324-329.

Eko Wiyono, S., \& Latipah. (2017). Penerapan Metode Simple Additive Weighting (SAW) Pada Sakinah Supermarket Untuk Pemilihan Karyawan Terbaik. Jurnal Link, 26(1), 24-28.

Firdaus, dkk. (2018). Implementasi Simple Additive Weighting untuk Rekomendasi Pencari Kerja Terbaik Dalam Sistem Informasi Lowongan Kerja Jurnal Edik Informatika. Jurnal PILAR Nusa Mandiri, 2.il(1), 25. https://doi.org/10.30872/jim.v10i2.187

Manullang, A. P., Prahutana, A., \& Santoso, R. (2018). Penerapan metode simple additive weighting (SAW) dan weighted product (WP) dalam sistem penunjang pemilihan laptop terfavorit menggunakan gui matlab. Jurnal Gaussian, 7(2018), 11-22.

Poernomo, B. (2017). Sistem Pendukung Keputusan Penerimaan Karyawan Baru Di Departemen Kehakiman Timor - Leste Dengan Menggunakan Metode SAW. POSITIF: Jurnal Sistem Dan Teknologi Informasi, 3(1), 10 https://doi.org/10.31961/positif.v3i1.397

Refiza. (2019). Penerapan Metode Simple Additive Weighting ( Saw ) Untuk Seleksi Tenaga Kerja. Seminar Nasional Teknik (SEMNASTEK) UISU.

Salim, M. A. (2018). Sistem Pendukung Keputusan Pemilihan Penerima Bantuan Perbaikan Rumah Menggunakan Metode Simple Additive Wieghting (SAW) Studi Kasus Kelurahan Tambelan Sampit Kota Pontianak. Jurnal SISTEMASI, 7(2), 120-131. https://doi.org/DOI : https://doi.org/10.32520/stmsi.v7i2.293.g124

Virgoreta, D. (2016). Implementasi Program Keluarga Harapan (PKH) Dalam Upaya Meningkatkan Kesejahteraan Masyarakat (Studi Pada Desa Beji Kecamatan Jenu, Kabupaten Tuban). Jurnal Administrasi Publik Mahasiswa Universitas Brawijaya, 3(1), 1-6.

Yulianti, E., \& Roki. (2018). Sistem Pendukung Keputusan Seleksi Penerima Bedah Rumah Menggunakan Metode Simple Additive Weighting (SAW) (Studi Kasus: Dinas Sosial Dan Tenaga Kerja Kota Padang). Jurnal Teknoif, $6(2)$, 64-73. https://doi.org/10.21063/jtif.2018.v6.2.64-73 